Katarzyna Ponikowska

University of Silesia e-mail: katarzyna.ponikowska@us.edu.pl

\title{
CITTASLOW IDEAS AS ELEMENTS OF BUILDING A TERRITORIAL BRAND. A CASE STUDY OF KALETY
}

\begin{abstract}
The article covers the topic of implementing Cittaslow ideas into a territorial branding strategy. The study is based on a Kalety case study, the town located in a postindustrial Silesian area. The author presents main theoretical issues of place branding along with those connected with functioning of a Cittaslow network.
\end{abstract}

Keywords: Cittaslow, territorial brand, sustainable development

\section{Streszczenie}

\section{Idee Cittaslow jako element strategii kreowania marki miejsca. Przypadek Kalet}

Poniższy tekst dotyczy wykorzystania przez stosowne instytucje idei zawartych w manifeście sieci Cittaslow do budowania marki miejsca na przykładzie Kalet, położonych na postindustrialnych terenach Śląska. Autorka przedstawia założenia dotyczące budowania marki miejsca oraz podstawowe informacje związane $\mathrm{z}$ funkcjonowaniem sieci miast Cittaslow w Polsce i na świecie, ze szczególnym uwzględnieniem warunków koniecznych do realizacji przez miasta aspirujące.

Słowa kluczowe: sieć Cittaslow, marketing miejsca, rozwój zrównoważony

\section{Introduction}

Implementing ideas contained in a sustainability concept may help small towns face problems typical for them, rooted in historical, economic and social changes of the last decades. Some kind of tension in an urban tissue, in its spatial and socio-cultural dimension leaves an imprint on those human settlements, where 
services market and alternative for industrial (or farming) work places are to the great extent limited.

One of the forms in which ideas of sustainable development can be transformed into real life activities is Cittaslow, manifestation of a Slow Life movement. The concept of Cittaslow was born in 1998 in Italy, as an initiative introduced by Paulo Saturnini. In Poland first towns joined this network in 2004, and now increased the number of members up to 27 located mainly in Warmia-Masuria Voivodeship [Cittaslow]. Some of them are also located in different parts of Poland, which obviously connects with their different features, characterized by diverse demographic, historical and social background.

The main aim of this article is to present the way the authorities of Kalety used the ideas included in Cittaslow movement manifesto, along with tools offered by the network and other institutions encouraged by the fact Kalety is its member (like EU programs), to develop territorial marketing and promote the town. Kalety is, if at all, most commonly associated with heavy industry and consequences of closing it for the employee market, not promotion of ecologically friendly lifestyle and space management [Strategia rozwoju..., 2012: 18]. In general we can talk about two main approaches to the analysis of the place image attributes [DudekMańkowska, Balkiewicz-Żerek, 2015: 18]. One of them is based on quotative methods, such as semantic differential or a Likert scale, another one is built upon qualitive methods, where data are collected with such tools as focus interviews, in-depth interviews, on-desk research or just observation. The main research problem is the shape of the promotional strategy of Kalety based, directly or indirectly, on the ideas of Cittaslow and the fact of being a member of the network. The problem is to be analyzed by answering question/s: to what extent Kalety responds to the idea of Cittaslow, what is its potential, how is this potential converted into real activity and investments located in the town, who are the main players in the game? Thus the main aim of the article is to adduce examples of how its authority exploits the potential of being a member of Cittaslow network. In order to gather relevant materials desk research methodology was implemented. Secondary sources such as the development strategy for the town, revitalization program, joining Cittaslow evaluation documents, website, other promotional materials etc. were analyzed.

\section{Territorial branding}

A definition of a brand itself has been constructed by many theorists. The most suitable for the idea of the article seems to be the following one describing it as a customer experience represented by a collection of images and ideas. Often, it refers to a symbol such as a name, logo, slogan, and design scheme. Brand recognition and other reactions are created by the accumulation of experiences with the specific product or service, both directly relating to its use, and through the influence of advertising, design, and media commentary [SEMPO...]. 
A brand can be attached not only to a product, a person, an organization but also to a territory. Drawing parallels between the brand image of a product or corporation or service and the image of a country or city or region is both logical and legitimate, because both depend on the health and power of that image [Editorial Team, 2015a: 7].

A process of developing the strength and recognition of a place is concerned as a place marketing. It may be understood as a practice involving the application of branding and sales strategies to different regions, cities, states or countries [Business Dictionary]. This process can also be called a territorial marketing or place branding, which is understood as discovering, creating, developing and realizing ideas and concepts for reconstructing place identities, and subsequently building the sense of place, by efforts and investments in hardware (e.g. infrastructure, buildings), software (e.g. events, stories), org-ware (e.g. co-operative organizational structuring) and virtual ware (e.g. symbols and symbolic actions, websites) [Govers, Go, 2009]. According to Kotler place marketing may be perceived as a philosophy and skill set dedicated to market and improve a place and develop a core image that can attract visitors, residents, industries and companies [Editorial Team, 2015a], whereas Anholt concludes: that marketing, the development, promotion, distribution and sale of products and services, is a legitimate, tangible and measurable activity with direct business benefits, whereas a brand is rather an academic construct, a psychological process, a phenomenon for observation [Anholt, 2010].

Govers, van 't Klooster, van Keken developed a set of Place Branding Principles to guide the brand development and management of cities, regions, destinations and countries. They are as follows: distinctiveness, authenticity, memorable, co-creation, place making [Editorial Team, 2015b].

\section{Cittaslow movement}

The movement of Cittaslow was born in 1998 as an initiative of Paolo Saturnini, at that time the mayor of Greve in Chianti, a town of Tuscany, Italy. A year later, as his ideas were endorsed by mayors of other Italian towns of Bra, Orvieto and Positano, four Italian cities set up an International Association of Cittaslow to become now a network of 236 settlements with less than 50,000 inhabitants, in 30 countries all over the world [Cittaslow International]. The main goal of Cittaslow, was and still is today, to enlarge the philosophy of Slow Food to local communities and to government of towns, applying not only the concepts of ecogastronomy at practice of everyday life, but also the new idea of considering the town itself and thinking of a different way of development, based on the improving of life quality, moved him to spread his thoughts all over our country [Association | Cittaslow...]. As the main idea of the network states: 
Municipalities which join the association are motivated by curios people of a recovered time, where man is still protagonist of the slow and healthy succession of seasons, respectful of citizens' health, the authenticity of products and good food, rich of fascinating craft traditions of valuable works of art, squares, theaters, shops, cafés, restaurants, places of the spirit and unspoiled landscapes, characterized by spontaneity of religious rites, respect of traditions through the joy of a slow and quiet living [Association | Cittaslow...].

The Cittaslow agenda represents a viable model for alternative urban development, which is sensitive and responsible to the interdependences between the goals for economic development, environmental protection, and social equity [Mayer, Knox, 2006: 321]. It is somehow related to the trend of the $21^{\text {th }}$ century to appreciate the potential of small towns and the assumptions of sustainable development. Member cities adopt common targets for improving the quality of life and cultivate the culture of good living. They rely on social and environmental activities to preserve the unique character of each city, through the restorations of monuments and fostering local production, crafts and cuisine [Cittaslow - inna...].

In 2006 first Polish city joined the organization to establish Polish Cittaslow Network several months later. Now there are 28 municipalities belonging to the Polish branch of the Cittaslow network. 20 of them are located in Warmia and Masuria region. In 2015 they established "Polish Cittaslow Cities" on the basis of 11 cities - current members of Polish National Cittaslow Network. The association is a partner for the Warmian-Mazurian Voivodeship in the implementation of Local Revitalization Programme of the Network of Cittaslow Cities, co-financed by Regional Operational Programme Warmia and Masuria for 2014-2020. The creation of the Association provides an opportunity to gain more external resources, especially for Cittaslow movement [Cittaslow - Association]. In 2013, the town started a procedure for accession to the International Cittaslow Association. Official membership certificate was given to the town at $7^{\text {th }}$ General Assembly in Netherlands, on 21 June 2014 [Miasto Kalety...].

Kalety is the only one town located in Upper Silesian Voivodeship. Therefore, though cooperating closely with other partner cities, it does not have an equivalent, direct support from the regional similar organization. Location in a region commonly associated rather with industry than environmental sensitiveness is quite crucial for territorial brand building of this town. It is important to implement changes in a town image which would reflect development opportunities of Kalety. Its promotion has to become one of the most important activities in the town strategy, mainly because of its stereotypical perception as a little attractive place coping with postindustrial and environmental problems [Strategia rozwoju..., 2012: 10].

Kalety is a town situated in the south of Poland, in Upper Silesia, and is part of the Silesian province and Tarnowskie Góry district. The town spreads in a vast, flat valley, on the Mała Panew river. The total area of the town is $76.68 \mathrm{~km}^{2}$ with the population of 8,616 (2016) inhabitants [Miasto Kalety...; Urzad Statystyczny...].

The beginnings of this settlement are closely associated with the rise of steel industry in Upper Silesia. Metallurgical traditions had been cultivated here from 
the fourteenth until the $19^{\text {th }}$ century. At the end of the $18^{\text {th }}$ century, John Koulhaas - an industrialist, innovator and owner of several plants producing steel bought the local forge, and later, in 1789, founded a new plant of files, spoons, knives, forks and buttons. The plant and the nearby located sawmill, which were bought then in the mid- $19^{\text {th }}$ century by the Counts von Donnersmarck from Świerklaniec, became the nucleus of a new business that Kalety was famous for almost the entire $20^{\text {th }}$ century - the pulp and paper factory. Today, there are no major industrial plants in Kalety and the local economy is driven by small family businesses mainly. Several of them have been established in the deaths of the pulp and paper factory [Miasto Kalety...]. Life of the town was organized around functioning of the plant, therefore it could be characterized rather by a monocultural character of social and economical commune organization. On the one hand it enabled development of cultural and sport institutions and infrastructure, on the other, though, pollution coming from the factory had an hazardous impact on the environment [Strategia rozwoju..., 2012: 3].

\section{Cittaslow ideas in Kalety territorial branding}

After the factory ceased its activity in 1994, the town itself has begun a new era in its history and by enhancing and promoting the values and advantages of the picturesque location it has become "Forest Corner of Silesia".

Problems diagnosed as being basic issues to be solved by local authorities and other bodies:

- economic situation after closing the pulp and paper factory,

- state of natural environment,

- exodus of young people due to economic and social situation,

- lack of well-organized tourist accommodation system,

- poor commitment of inhabitants into social activity [Strategia rozwoju..., 2012: 3].

Consequently, the objectives of Kalety development program were defined as necessity to:

- use existing natural resources, especially forest areas to improve quality of inhabitants life and attract tourists,

- transform Kalety into a place with wide range of possibilities to spend freetime activities for population of Silesian Agglomeration,

- build local community strength based on shared values, which members are aware of local potential in the perspective of global changes,

- stimulate activity of local economy by attracting external investors,

- sustain demographic potential of the town [Strategia rozwoju ..., 2012: 3].

As may be noticed most, if not all, of above mentioned points are also implemented in a Cittaslow development strategy.

Though we read in a local strategy about limited potential of natural resources as a factor generating town development, forest area located around seems to 
make one of the main points exploited in a territorial promotion policy. The beautiful location among forests ( $80 \%$ of the municipality area) provides potential to attract tourists. With the guests and their inhabitants in view, the town is steadily and constantly increasing its attractiveness by cultivating parks, paving and marking biking routes and lanes for jogging and nordic-walking. For this same purpose, in the current year, the sports stadium has been renovated and the stadium's infrastructure has been significantly enriched. In cooperation with five neighboring municipalities, in 2013 there was opened a trail called "Leśno Rajza" (Forest Tour) which is 150 kilometers long. Cycling tours and cross-country events are regularly organized there [Miasto Kalety...]. All the above may be noticed in a strategy and revitalization program for the city and are implemented by the local authority and activists in Kalety.

To become a member city of the network Kalety, as any other aspiring town, had to meet 72 requirements for quality listed in seven macro groups: energy and environmental policies, infrastructure policies, quality of urban life policies, agricultural, touristic and artisan policies, policies for hospitality, awareness and training, social cohesion and partnerships [How to become...].

Table 1

Present activities in Kalety - also elements of territorial branding - in reference to Requirements for Quality - examples

\begin{tabular}{|c|c|c|c|}
\hline No. & $\begin{array}{l}\text { Requirements for } \\
\text { quality: macro areas }\end{array}$ & $\begin{array}{l}\text { Mean value for } \\
\text { Kalety at the } \\
\text { time of joining } \\
\text { the Cittaslow } \\
\text { network (\%) }\end{array}$ & $\begin{array}{l}\text { Present activities - also elements } \\
\text { of territorial branding }\end{array}$ \\
\hline 1. & $\begin{array}{l}\text { Energy and environmental } \\
\text { policies } \\
\text { Parks and green areas, re- } \\
\text { newable energy, transport, } \\
\text { recycling, etc. }\end{array}$ & 76 & $\begin{array}{l}\text { - Leśno Rajza (Forest Tour) } \\
\text { - "Zielona" (Green) recreation area } \\
\text { - Ichtiopark } \\
\text { - Termomodernization of public utility } \\
\text { buildings } \\
\text { - Joining projects for alternative energy } \\
\text { sources use: a photovoltaic farm on a city } \\
\text { hall building, } 400 \text { households supplied with } \\
\text { solar batteries or photovoltaic panels } \\
\text { - Award in category of energy efficient } \\
\text { buildings in a competition ECO city, orga- } \\
\text { nized by French Embassy }\end{array}$ \\
\hline 2. & $\begin{array}{l}\text { Infrastructure policies } \\
\text { Alternative mobility, cycle } \\
\text { paths, street furniture, etc. }\end{array}$ & 80 & $\begin{array}{l}\text { - Leśno Rajza (Forest Tour) } \\
\text { - Award of PTTK for a Cyclists Friendly } \\
\text { Municipality }\end{array}$ \\
\hline 3. & $\begin{array}{l}\text { Quality of urban life poli- } \\
\text { cies } \\
\text { Requalification and reuse } \\
\text { of marginal areas, cable } \\
\text { network city (fibre optics, } \\
\text { wireless), etc. }\end{array}$ & 83 & $\begin{array}{l}\text { - Plans for building a swimming-pool as } \\
\text { an attraction for neighborhood towns and } \\
\text { tourists } \\
\text { - "Zielona" (Green) recreation area } \\
\text { - Ichtiopark }\end{array}$ \\
\hline
\end{tabular}




\begin{tabular}{|c|c|c|c|}
\hline 4. & $\begin{array}{l}\text { Agricultural, touristic } \\
\text { and artisan policies. Pro- } \\
\text { hibiting the use of GMO } \\
\text { in agriculture, increas- } \\
\text { ing the value of working } \\
\text { techniques and traditional } \\
\text { crafts, etc. }\end{array}$ & 77 & $\begin{array}{l}\text { - Promotion and support for an idea of sus- } \\
\text { tainable and consistent architecture } \\
\text { - Leśno Rajza (Forest Tour) } \\
\text { - "Zielona" (Green) recreation area } \\
\text { - Ichtiopark } \\
\text { - Promotion of a bee habitat protection } \\
\text { programme }\end{array}$ \\
\hline 5. & $\begin{array}{l}\text { Policies for hospitality, } \\
\text { awareness and training. } \\
\text { Good welcome, increasing } \\
\text { awareness of operators and } \\
\text { traders (transparency of } \\
\text { offers and practiced prices, } \\
\text { clear visibility of tariffs), } \\
\text { etc. }\end{array}$ & 80 & $\begin{array}{l}\text { - Placing information about most of activi- } \\
\text { ties and promotional materials on a town } \\
\text { website and social media } \\
\text { - Placing and spotlighting the logo of Cit- } \\
\text { taslow on a town website and all promo- } \\
\text { tional materials, as well as in some spots in } \\
\text { the public space } \\
\text { - Programmes for kindergarten and school } \\
\text { pupils teaching pro-environmental attitudes } \\
\text { - Due to preparation of the project "Local } \\
\text { Program of Kalety Revitalisation till 2023" } \\
\text { the Mayor launched public consultation on } \\
\text { the project }\end{array}$ \\
\hline 6. & $\begin{array}{l}\text { Social cohesion } \\
\text { Integration of disable } \\
\text { people, poverty, minorities } \\
\text { discriminated, etc. }\end{array}$ & 30 & $\begin{array}{l}\text { - Offers for senior citizens } \\
\text { - Participation in a running event support- } \\
\text { ing a charity action "Wings for life" }\end{array}$ \\
\hline 7. & $\begin{array}{l}\text { Partnerships } \\
\text { Collaboration with other } \\
\text { organizations promoting } \\
\text { natural and traditional } \\
\text { food, etc. }\end{array}$ & 46 & $\begin{array}{l}\text { - Promotion of a local product called } \\
\text { "kaleśnik" (Kalety + naleślnik), a kind of } \\
\text { pancake } \\
\text { - Partner cities, eg. Vitkov in Czech Republic }\end{array}$ \\
\hline
\end{tabular}

Source: own elaboration based on [How to become...] and the Kalety City Hall reports.

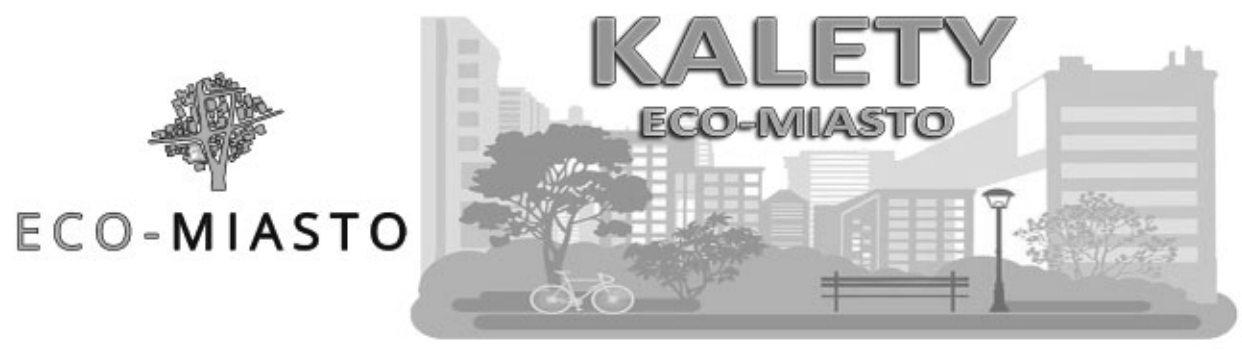

Picture 1. Promotional slogan coming from a certificate Kalety was granted in category of energy efficient buildings, in a competition ECO city, organized by French Embassy (designed by Marek Parys)

Source: Miasto Kalety... 
A brand is not given for once and for good. It is a kind of process and its strength may increase or decrease at times. In the case of Kalety the image of the city has had to overcome a process of reconstruction from being associated with dominated industrial profile into the one being rooted in values connected with natural environment and social and ecological sustainability. It is still undergoing the process of transformation, usually with quite interesting results. However, there are still some areas which require closer look and deeper engagement from stakeholders. One of them is definitely social cohesion. In an evaluation report this aspect received the poorest notes. It is not surprising though, as changing human state of mind, values system and resulting from them activities are more time consuming and more sophisticated processes than on the spot actions.

Five Place Branding Principles, mentioned above, may constitute an adequate ground for analyzing Kalety territorial branding and be treated as a tool for diagnosing indicators of building a brand in such type of town.

Table 2

Ways of meeting Five Place Branding Principles by Kalety

\begin{tabular}{|c|c|c|}
\hline No. & Five place branding principles & $\begin{array}{l}\text { Forms of realizing the principles in Kalety } \\
\text { in reference to Cittaslow ideas and con- } \\
\text { nected events (examples) }\end{array}$ \\
\hline 1. & $\begin{array}{l}\text { Distinctiveness } \\
\text { What makes the place unique when } \\
\text { compared to other places? } \\
\text { What are the core values of the place's } \\
\text { brand? } \\
\text { What is the brand promise? }\end{array}$ & $\begin{array}{l}\text { - Information about membership in the citta- } \\
\text { slow network underlined on the town website, } \\
\text { in promotional material and development } \\
\text { strategy } \\
\text { - Spotlighting, in marketing materials, in- } \\
\text { formation about } 80 \% \text { of the area covered by } \\
\text { forests } \\
\text { - Core values refer to the idea of sustainabil- } \\
\text { ity implemented in cittaslow manifesto (e.g. } \\
\text { life quality, local products promotion, envi- } \\
\text { ronmental protection, hospitality) } \\
\text { - Live or spend your free time in a friendly } \\
\text { natural environment }\end{array}$ \\
\hline 2. & $\begin{array}{l}\text { Authenticity } \\
\text { It is about people co-creating things } \\
\text { that matter to them. } \\
\text { A broad solid basis for the place brand is } \\
\text { established by involving stakeholders in: } \\
\text { - the identification of key characteristics } \\
\text { of the place brand inspired by the iden- } \\
\text { tity or sense of place, } \\
\text { - finding the link with existing perceived } \\
\text { and projected images in relevant markets } \\
\text { (i.e. what do people currently think and } \\
\text { say about us), and } \\
\text { - the design of authentic customised and } \\
\text { co-created place experiences in practice }\end{array}$ & $\begin{array}{l}\text { - Information about activities moderated by } \\
\text { the authorities are shared via different chan- } \\
\text { nels, eg a website } \\
\text { - A project of a new revitalization program } \\
\text { was consulted with the inhabitants } \\
\text { - Local people are encouraged to participate } \\
\text { in events connected with cittaslow network } \\
\text { activities, eg. the Cittaslow festival } \\
\text { - Ideas connected with cittaslow and used for } \\
\text { promoting the town are spread among mem- } \\
\text { ber of the community (eg schools) } \\
\text { - Inhabitants and tourists are informed about } \\
\text { the place potential }\end{array}$ \\
\hline
\end{tabular}




\begin{tabular}{|l|l|l|}
\hline 3. & $\begin{array}{l}\text { Memorable } \\
\text { When a place has a unique and distinc- } \\
\text { tive sense of place, it becomes memo- } \\
\text { rable. Memorable means that the enjoy- } \\
\text { able experience at that certain place, } \\
\text { conquered space in your mind and your } \\
\text { heart. So that you might think of living } \\
\text { or investing there, or return one day }\end{array}$ & $\begin{array}{l}\text { - Local authorities make people remember } \\
\text { about connection between Kalety and the } \\
\text { cittaslow network (logo put in key points of } \\
\text { the town, much information about social and } \\
\text { environmental projects placed in media) }\end{array}$ \\
\hline $\begin{array}{l}\text { Co-Creation } \\
\text { Place branding is not a top-down ex- } \\
\text { ercise but will only produce the best } \\
\text { results when it is created and maintained } \\
\text { through a strong coalition between } \\
\text { government, business, civil society and } \\
\text { target markets (investors, expats, travel } \\
\text { trade, press) }\end{array}$ & $\begin{array}{l}\text { (Dziennik Zachodni, facebook, forum, utube } \\
\text { etc.) } \\
\text { - Evaluation and feedback from inhabitants } \\
\text { are collected } \\
\text { - Local people take part in activities in some } \\
\text { way connected with above issues (creation of } \\
\text { a cittaslow symbol) }\end{array}$ \\
\hline 5. & $\begin{array}{l}\text { Place Making } \\
\text { Place branding is not about a good } \\
\text { slogan, logo and nice promotional } \\
\text { campaigns. In the experience economy } \\
\text { an integrative place branding strategy is } \\
\text { needed to capture the hearts and atten- } \\
\text { tion of visitors. This means that the place } \\
\text { brand should be supported by policies, } \\
\text { innovations, events, structures, invest- } \\
\text { ments and symbolic actions }\end{array}$ & $\begin{array}{l}\text { - All undertakings located in Kalety and its } \\
\text { neighborhood mentioned in the text along } \\
\text { with those which take place in this munici- } \\
\text { pality and are not brought up here are meant } \\
\text { a create a consistent image of the town as } \\
\text { rial branding to nature, are tools of its territo- }\end{array}$ \\
\hline
\end{tabular}

Source: own analysis based on: Editorial Team, 2015b.

Territorial brands must be consistent, easily identified and offering explicit values concept of the place [Zdon-Korzeniowska, 2012: 132]. Kalety seems to build its core values around areas directly or indirectly connected with Cittaslow ideology. Both, the Kalety Development Strategy and its Revitalization Program include points which are identical with those from the Cittaslow manifesto.

\section{Conclusions}

A territorial brand is a medium of the virtues in a given region, represents typical values of the region, induces a set of associations with the area as a whole unity, shows differences between the region and other parts of the land, increases trust into local government, makes people loyal to local products, symbols etc. Gaining such equilibrium may be a real challenge for the local government, especially in the field of social cohesion and cooperativeness. For many small towns finding a way, some kind of "foothold", a vision for further development in a changing 
world is crucial, in terms of prosperity or at least chance to cope and survive gaining a relatively satisfying level of life quality in a changing world. Kalety spotted the chance for its development in being perceived as community aware of its potential hidden, in the middle of green areas, in a characteristic location. The location which, to the some extent, has become a background and source of ideas for the place/settlement branding strategy.

Power of a brand can be explained through two dimensions: strength to compete and sustainability in future [Brandirectory]. Brand power can be also understood as a distinctive feature of brand personality, positive and meaningful image, logic and consistent aspect of its communication along with integrity of its identity [Dudek-Mańkowska, Balkiewicz-Żerek, 2015: 17] and from these perspectives Kalety may be perceived as being on the right pathway.

Issues connected with small cities from the network are also a topic of consideration in European Parliament. In January 2018 in Brussels the authorities of the Cittaslow International and a group of European MPs met to discuss the ways of supporting sustainable development and life quality improvement in small cities. This initiative is also to focus attention of European Union on the problems of this type of settlements, especially in a scope of environmental protection, cultural heritage and supporting local activities [Cittaslow - inna...]. Thus idea is spreading and may become an inspiration for other communities facing problems of social and/or environmental degradation.

\section{References}

Anholt S. (2010), Definitions of Place Branding - Working towards a Resolution, "Place Branding and Public Diplomacy", 6, http://citeseerx.ist.psu.edu/viewdoc/download?doi=10.1.1. 470.7023\&rep=rep1\&type=pdf [accessed: 20 February 2018].

Dudek-Mańkowska S., Balkiewicz-Żerek A. (2015), Siła marki miejsca, "Marketing i Rynek", 6.

Editorial Team (2015a), Interview with Philip Kotler on Place Marketing and Branding, https://placebrandobserver.com/interview-philip-kotler [accessed: 7 March 2018].

Editorial Team (2015b), 5 Place Branding Principles for Successful Brand Development and Management, https://placebrandobserver.com/5-place-branding-principles-to-guide-brand-development-management [accessed: 7 March 2018].

Govers R., Go F. (2009), Place Branding: Glocal, Virtual and Physical Identities. Constructed, Imagined and Experienced, Palgrave Macmillan, s. 1.

Kwiatek-Sołtys A., Mainet H. (2015), Cittaslow, a Qualitative Approach to Small Towns' Local Development,

Mayer H., Knox P.L. (2006), Slow Cities: Sustainable Places in a Fast World, "Journal of Urban Affairs", 4 (28).

Strategia rozwoju miasta Kalety do roku 2025 (2012), http://bip.kalety.pl/upload/Zalacznik\%20Nr\%201\%20[Strategia\%20Miasta\%20Kalety].pdf [accessed: 24 February 2018]. 
Zdon-Korzeniowska M. (2012), Budowa marki regionalnej na wybranych przykładach województw Polski, "Prace Komisji Geografii Przemysłu", 19.

\section{Internet sources}

Association | Cittaslow International, http://www.cittaslow.org/content/association [accessed: 22 February 2018].

Brandirectory, http://brandirectory.com [accessed: 21 February 2018].

Business Dictionary, [place marketing - definition], http://www.businessdictionary.com/definition/place-marketing.html [accessed: 22 February 2018].

Cittaslow - Association, http://cittaslowpolska.pl/index.php/en/association [accessed: $22 \mathrm{Fe}-$ bruary 2018].

Cittaslow. Inna strona nowoczesności, http://cittaslowpolska.pl [accessed: 22 February 2018].

Cittaslow International, http://www.cittaslow.org [accessed: 22 February 2018].

How to become | Cittaslow International, http://www.cittaslow.org/content/how-become [accessed: 22 February 2018].

Miasto Kalety. Leśny zakątek Ślaska, http://kalety.pl [accessed: 22 February 2018].

SEMPO: Search Engine Marketing Professionals Organization, http://www.sempo.org [accessed: 22 February 2018].

Urząd Statystyczny w Katowicach, http://katowice.stat.gov.pl [accessed: 22 February 2018]. 